\title{
EFEK PROTEKTIF ZINK TERHADAP STRES OKSIDATIF TESTIS DAN KUALITAS SPERMA PADA MENCIT JANTAN (Mus musculus) SETELAH DIINDUKSI CYCLOPHOSPHAMIDE
}

\author{
Retno Yulianti*1, Tiwuk Susantiningsih ${ }^{2}$, M Ibnu Khaldun ${ }^{3}$, M Fadzrul Adhiwirawan ${ }^{4}$ \\ ${ }^{1,2,3}$ Fakultas Kedokteran Universitas Pembangunan Nasional Veteran Jakarta \\ *1e-mail : dr.retnoyulianti@gmail.com
}

\begin{abstract}
Cyclophosphamide is a class of alkylating agents used for cancer treatment. The side effect of $\mathrm{CP}$ is through the depletion mechanism of the GSH cellular pathway which generates free radicals by activation by copper/iron in the body to damage the spermatogenesis process. Zinc has antioxidant enzymes and can bind metallothionein to protect the body from the effects of anti-cancer drugs. The purpose of this study was to determine the protective effect of $\mathrm{Zn}$ against testicular oxidative stress and sperm quality in male mice (Mus musculus) after cyclophosphamide induction. This study used 30 male mice divided into six groups, namely negative controls that were not given $\mathrm{CP}$ and $\mathrm{Zn}$ (K1), positive controls that were given only $\mathrm{Zn}(\mathrm{K} 2)$ and only $\mathrm{CP}(\mathrm{K} 3)$ and groups that were given $\mathrm{CP}$ injections $(200 \mathrm{mg} / \mathrm{Kg})$ with 3 doses of Zn, namely $25 \mathrm{mg}$ (K4), $50 \mathrm{mg}$ (K5) and $100 \mathrm{mg}$ (K6). The analysis showed that the mean sperm quality in all groups was significantly different $(\mathrm{p}=0.011)$. The mean levels of MDA testis in all groups did not differ significantly. There was no relationship between testicular MDA levels with sperms quality $(\mathrm{p}=0.800)$ and the degree of correlation in a negative direction $(\mathrm{R}=-0.048)$. This study concluded that testicular MDA levels are not associated with sperms quality, especially the number of sperms cells.
\end{abstract}

Keywords : cyclophosphamide, malondialdehid, sperms, zinc

\begin{abstract}
Abstrak
Cyclophosphamide $(C P)$ merupakan golongan alkylating agent yang digunakan untuk pengobatan kanker. Efek samping CP melalui mekanisme deplesi jalur seluler GSH yang menghasilkan radikal bebas dengan aktivasi oleh tembaga atau besi dalam tubuh sehingga merusak proses spermatogenesis. Zink ( $\mathrm{Zn}$ ) memiliki enzim-enzim antioksidan dan mampu mengikat metallothionein untuk melindungi tubuh dari efek obat anti kanker. Tujuan penelitian ini untuk mengetahui efek proteksi zink terhadap stress oksidatif testis dan kualitas sperma pada mencit jantan (Mus musculus) setelah diinduksi cyclophospamid. Penelitian ini menggunakan 30 mencit jantan yang dibagi enam kelompok yaitu kontrol negatif yang tidak diberi CP dan Zn (K1), kontrol positif yang hanya diberi $\mathrm{Zn}(\mathrm{K} 2)$ dan hanya CP (K3) serta kelompok yang diberikan penyuntikan CP (200 mg/Kg) dengan 3 dosis Zn yaitu 25 mg (K4), $50 \mathrm{mg}$ (K5) dan $100 \mathrm{mg}$ (K6). Hasil analisis menunjukkan rerata kualitas sperma (jumlah sel sperma) pada semиa kelompok berbeda siginifikan $(p=0.011)$. Rerata kadar MDA testis pada seтиa kelompok tidak berbeda signifikan. Tidak terdapat hubungan antara kadar MDA testis dengan kualitas sperma (jumlah sel sperma) $(p=0.800$, $p>0.05$ ) dan derajat korelasi ke arah negatif (nilai $R=-0.048$ ) Kesimpulan penelitian ini bahwa kadar MDA testis tidak berhubungan dengan kualitas sperma terutama jumlah sel sperma.
\end{abstract}

Kata Kunci: cyclophosphamide, malondialdehid, sperma, zink 


\section{PENDAHULUAN}

Menurut data International Agency for Research on Cancer (IARC) pada tahun 2012 bahwa terdapat 14.067.894 kasus baru kanker dan 8.201.575 kematian akibat kanker di seluruh dunia. Penyebab kematian utama di seluruh dunia salah satunya adalah penyakit kanker (Pusdatin kementrian RI, 2015). Salah satu pengobatan kanker yang dianjurkan adalah kemoterapi dengan menggunakan beberapa obat antikanker dalam kombinasi regimen. Salah satu obat yang ada dalam kombinasi regimen obat kanker adalah cyclophosphamide (CP) (Perhimpunan Dokter Paru Indonesia, 2003). Lebih dari 50\% pasien laki-laki yang menderita jenis tumor padat mendapatkan kemoterapi, namun efek dari kemoterapi tersebut menyebabkan pasien mengalami kerusakan berat pada epitel seminiferus yang berakhir dengan kemandulan (Abarikwu, S.O, 2012).

Cyclophosphamide (CP) merupakan alkylating agent dari golongan nitrogen mustard dalam kelompok oxazophorin. Cyclophosphamide akan mengalami aktivasi oleh enzim sel hepatosit yaitu Cytochrome P450 enzyme system (CYP) yang selanjutnya akan menjadi 2 unsur kimia berupa zat aktif sebagai ankylating agent, dan zat buangan hasil metabolit yaitu Phosparamide Mustard (PM) dan Acrolein. Sifat Acrolein sebagai aldehyde reactive menjadi penyebab utama efek samping CP yang dapat merusak sel dengan mekanisme deplesi jalur seluler GSH yang terkonjugasi oleh Acrolein, sehingga proses cytotoxicity dapat terjadi secara luas. Acrolein juga memiliki efek terhadap DNA yang menyebabkan terbentuknya Interstrand DNA dan DNA-protein cross-links sehingga akan mengganggu proses replikasi DNA normal tubuh (BC Cancer Agency Cancer Drug Manual@, 2013). Paparan CP dapat menyebabkan gangguan keseimbangan reaksi oksidatif jaringan sehingga menimbulkan stress oksidatif jaringan. Hasil reaksi akan terbentuk hidrogen peroksida yang mampu menyebabkan dekomposisi produk aldehid yang bersifat toksik terhadap sel dan berdampak pada gangguan perkembangan spermatogenesis (S. O.Abarikwu, 2012).

Untuk proses penghambatan tersebut, testis memiliki enzim - enzim antioksidan, yaitu superoksida dismutase, GSH Peroksidase dan Glutathione-s-transfarase (GST). Zink merupakan suatu konstituen dari superoksida dismutase, yakni suatu enzim yang dapat memproteksi sel-sel dari kerusakan yang disebabkan oleh stress oksidatif. Selama perkembangan sel sperma yang aktif secara metabolik akan memproduksi produk radikal bebas dan zink akan mengaktifkan sistem enzim yang menetralkan radikal bebas tersebut (Oktapiani, Kory; Wantouw; Tendean, 2014) Pada jalur counter oleh GSH peroksidase yang merupakan jalur utama untuk mengubah $\mathrm{H}_{2} \mathrm{O}_{2}$ menjadi $\mathrm{H}_{2} \mathrm{O}$ terhambat oleh konjugasi Acrolein, sehingga $\mathrm{H}_{2} \mathrm{O}_{2}$ nantinya akan mengalami perubahan struktur kimiawi menjadi spesies $\mathrm{OH}$ radikal dengan aktivasi oleh tembaga $(\mathrm{Cu})$ atau besi $(\mathrm{Fe})$ dalam tubuh dan merusak proses spermatogenesis pada testis. Hal ini yang mendasari untuk melakukan uji fungsi $\mathrm{Zn}$ yang mampu menghambat proses perubahan $\mathrm{H} 2 \mathrm{O} 2$ menjadi $\mathrm{OH}$ radikal melalui peran $\mathrm{Zn}$ sebagai antagonis terhadap $\mathrm{Cu} / \mathrm{Fe}$ sehingga tidak terjadi perubahan kimiawi tersebut. Selain itu $\mathrm{Zn}$ berfungsi untuk memproduksi molekul antoksidan yaitu metallothionein untuk melindungi tubuh dari paparan radiasi, efek obat - obatan anti kanker dan berbagai kondisi stress oksidatif lainnya. Selain itu juga Zink memiliki kemampuan menstimulasi hormon androgen (testosteron) pada sel Leydig, sehingga dalam proses spermatogenesis zink sangatlah berperan (Payaran, Wantouw , \& Tendean, 2014).

Berdasarkan latar belakang di atas, peneliti merasa tertarik untuk mengetahui sejauh mana pengaruh suplemen zink terhadap kualitas sperma terutama jumlah sel spermatozoa dengan menggunakan hewan uji mencit jantan (Mus musculus) yang diinduksi cyclophosphamide.

\section{METODE PENELITIAN}

\subsection{Persiapan Penelitian}

Jenis penelitian in vivo ini termasuk kategori true experimental. Metode perhitungan jumlah mencit dengan rumus Federer dan dilakukan 
3. Mengukur berat badan mencit sebelum diberi perlakuan dengan timbangan analitik.

4. Melakukan pemberian $\mathrm{Zn}$ pada 3 kelompok perlakuan (25 mg, $50 \mathrm{mg}$ dan $100 \mathrm{mg}$ ) per hari dan penyuntikan obat CP dengan dosis $200 \mathrm{mg} / \mathrm{kgBB}$ secara intraperitoneal 1 kali setiap minggu selama 35 hari. Untuk kelompok kontrol dibagi menjadi 1 kelompok kontrol negatif yaitu mencit yang diberi aquabidest tanpa diberi $\mathrm{CP}$ dan $\mathrm{Zn}$ dan 2 kelompok kontrol postitif yaitu mencit yang hanya diberi $\mathrm{Zn}$ tanpa $\mathrm{CP}$ dan mencit yang hanya diberi CP tanpa $\mathrm{Zn}$.

5. Penyuntikan obat $\mathrm{CP}$ secara intraperitoneal pada mencit kelompok perlakuan menggunakan handscoon steril menyiapkan $\mathrm{CP}$ yang dilarutkan dengan aquabidest $10 \mathrm{cc}$ di dalam vial, lalu lakukan homogenisasi larutan. Kemudian dengan syringe steril ukuran $3 \mathrm{ml}$ ambil $\mathrm{CP}$ sesuai dengan dosis yang telah dikonversi untuk mencit yaitu sebanyak 0,4 cc. Setelah itu ditunggu efek kerja obat $\mathrm{CP}$ selama 45 menit dan evaluasi keadaan mencit.

6. Menyiapkan $\mathrm{Zn}$ tablet yang dilarutkan dalam aquabidest dan sesuai dosis yang dikonversikan untuk mencit. Lakukan pemberian $\mathrm{Zn}$ pada 3 kelompok dosis perlakuan dan 1 kelompok kontrol positif yang hanya diberikan $\mathrm{Zn}$ sebesar $100 \mathrm{mg}$ dengan menggunakan sonde yang diberikan setiap hari pada pagi hari.

7. Setelah semua prosedur selesai, kembalikan mencit ke kandang mencit.

8. Setelah selama 35 hari dilakukan prosedur pemberian perlakuan ke masing- masing kelompok, selanjutnya melakukan pembedahan mencit untuk mendapatkan sel sperma dari epidydmis cauda dan kadar MDA dari organ testis.

\subsection{Parameter Uji}

\subsubsection{Pengambilan Sekresi Cauda Epididimis}

Prosedur mendapatkan sel sperma dengan mengambil epidydimis cauda mencit jantan yang telah dibedah, lalu epidydimis cauda dipotong secara crossectional halus hingga beberapa bagian kecil, lalu diletakkan dalam cawan petri yang berisi $\mathrm{NaCl} 0.9 \%$, kemudian dikeluarkan spermanya dengan cara 
dipencet lalu dihitung terlebih dahulu volume sperma dan kemudian ditetesi larutan George/ JOS dengan pengenceran 1000 x $(50 \mu \mathrm{l}$ sperma $+950 \mu \mathrm{l}$ lar George) sebanyak 2 tetes, kemudian lakukan homogenisasi agar mempermudah pemeriksaan.

\subsubsection{Perhitungan Jumlah Total Sperma Mencit}

Perhitungan sperma menggunakan hemasitometer Neubauer pada pembesaran 1000x, lalu dilakukan dengan menggunakan 5 kotak yang tersusun diagonal pada hemasitometer Neubauer, dan faktor pengeceran 1000 dengan nilai 20. Rumus perhitungan konsentrasi sperma $=\mathrm{N}$ x $10.000 \mathrm{x}$ $\mathrm{P} \times$ (Jum K x 0.25) ( $\mathrm{N}=$ jumlah sperma dari kotak yang dicacah, $\mathrm{P}=$ pengeceran yang dipilih $(10,20$ dan 50) dan yang pilih pengeceran $20, \mathrm{~K}=$ jumlah kotak yang dicacah dan ada 5 kotak yang dipakai, angka $10.000=$ mewakili satuan juta $/ 10^{6}$, nilai $0.25 \mathrm{~mm}=$ luas kotak kecil pada hemasitometer Neubauer. Nilai perhitungan adalah dalam satuan juta/mL dan dilakukan pada setiap kelompok, kemudian perhitungan jumlah total sperma mencit menggunakan rumus $=$ konsentrasi sperma x volume sperma.

\subsubsection{Penilaian Kadar MDA Jaringan Testis Mencit}

Pengukuran kadar MDA organ testis dilakukan dengan cara menimbang 1 gram jaringan testis yang sudah bersih lalu dihomogenasi di dalam tabung appendorf. Sampel testis ditambahkan $1 \mathrm{~mL}$ akuades. Pemeriksaan MDA dilakukan dengan penambahan Thiobarbituric acid (TCA) 20\% $200 \mu \mathrm{L}$ dengan homogenate $400 \mu \mathrm{L}$. Kemudian campuran divortex hingga terlihat keruh lalu disentrifugasi pada kecepatan $5000 \mathrm{rpm}$ selama 10 menit. Supernatan dari campuran tersebut diambil dan ditambahkan

$400 \mu \mathrm{L}$ larutan tiobarbiturat $0,67 \%$ kemudian panaskan dalam $95-100^{\circ} \mathrm{C}$ selama 10 menit lalu didinginkan. Sampel yang telah dingin dimasukkan dalam kuvet lalu diukur dengan spektrofotometri pada panjang gelombang 530 nm (Yulianti,R and Astari, R.V2020). Hasil pemeriksaan berupa nilai serapan yang kemudian dihitung kadar MDA menggunakan kurva standar.

\subsection{Analisis Data}

Pengolahan data dianalisis dengan menggunakan SPSS 17 dengan tingkat signifikansi 0,05 dan taraf kepercayaan 95\% $(\alpha=0,05)$ serta menggunakan uji One way ANOVA untuk mengetahui apakah terdapat perbedaan kadar MDA testis dan kualitas sperma pada semua kelompok. Selanjutnya untuk mengatahui letak perbedaan yang bermakna pada masing-masing kelompok dilakukan analisis post-hoc multiple comparison test serta untuk mengetahui hubungan antara kedua variabel dependen dengan menggunakan Pearson correlation test.

\section{HASIL DAN PEMBAHASAN}

\section{Kadar MDA jaringan testis mencit}

Untuk menilai suatu jaringan mengalami stress oksidatif berupa peningkatan radikal bebas yang berdampak pada kerusakan membran sel hingga kerusakan fungsi sel pada mitokondria dapat menggunakan indikator penilaian malondialdehid (MDA) yang merupakan senyawa hasil dari peroksidasi lipid pada membran sel. Hasil pemeriksaan kadar MDA jaringan testis menggunakan metode Thiobarbituric Acid Reactive Subtances (TBARs) didapatkan kadar MDA jaringan testis pada kelompok perlakuan yang mendapatkan Zink dosis $100 \mathrm{mg} / \mathrm{kgBB} / \mathrm{hari}$ (K6) yang diinduksi cyclophosphamide 200 $\mathrm{mg} / \mathrm{kgBB}$ lebih tinggi dibandingkan dengan kelompok kontrol negatif (K1), kelompok yang cenderung mendekati nilai kadar MDA kontrol negatif yaitu kelompok Zink dosis 25 $\mathrm{mg} / \mathrm{kgBB} /$ hari yang diinduksi cyclophosphamide $200 \mathrm{mg} / \mathrm{kgBB}$ sebagaimana terlihat pada Tabel 1 dan Gambar 1.

Tabel 1. Rerata kadar MDA testis (mikroMolar) mencit (Mus musculus) setelah perlakuan dengan pemberian Zink selama 35 hari. 


\begin{tabular}{|c|c|c|}
\hline Kelompok Perlakluan & Pengulangan & Kadar MDA Testis (mikroMolar) \\
\hline Kontrol Negatif & 5 & 11.90 .0 .59 \\
\hline Zink & 5 & $13.3 \pm 0.175$ \\
\hline Cyclophosphamide & 5 & $19.7 \pm 0.266$ \\
\hline Zink $25 \mathrm{mg} k \mathrm{kgBB}$ hari & 5 & $12.5 \pm 0.350$ \\
\hline Zink $50 \mathrm{mg} k \mathrm{kgBB}$ hari & 5 & 207.70 .201 \\
\hline Zink 100 mg kgBB hari & 5 & $34.7 \pm 0.335$ \\
\hline
\end{tabular}

Rerata Kadar MDA Testis Mencit

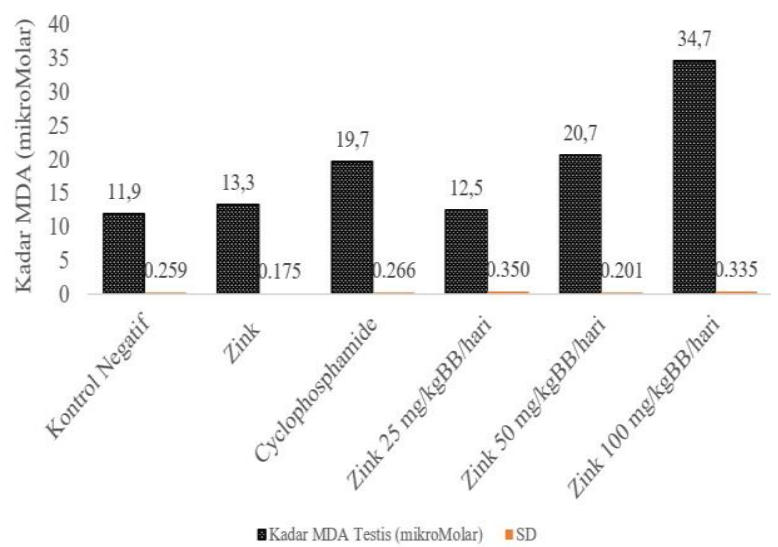

Gambar 1. Rerata kadar MDA testis mencit (Mus musculus) setelah perlakuan dengan pemberian Zink selama 35 hari.

Selanjutnya data tersebut dianalisis dengan uji statistik untuk membandingkan data kadar MDA testis pada semua kelompok perlakuan. Karena syarat uji One Way ANOVA terpenuhi yakni data terdistribusi secara normal dengan uji Kolmogorov-Smirnov nilai signifikansi $\mathrm{p}=0.837(\mathrm{p}>0.05)$ dan homogenitas data didapatkan homogen dengan uji Levene nilai signifikansi $\mathrm{p}=0.869(\mathrm{p}>0.05)$. Hasil uji disajikan pada Tabel 2.

Tabel 2. Hasil uji One Way ANOVA Rerata kadar MDA testis mencit (Mus musculus) pada kelompok perlakuan setelah perlakuan dengan pemberian Zink selama 35 hari.

\begin{tabular}{lccccc}
\hline Kelompok Perlakuan & $N$ & Rata-rata & SD & $\begin{array}{c}\text { Post Hoc test } \\
\text { Tukey HSD }\end{array}$ & $p$ \\
\hline Kontrol Negatif & 5 & 1.018 & 0.259 & 0.111 & 0.093 \\
\hline Zink & 5 & 1.092 & 0.175 & & \\
\hline Cyclophosphamide & 5 & 1.224 & 0.266 & & \\
\hline Zink 25 mgkgBB hari & 5 & 1 & 0.350 & & \\
\hline Zink 50 mgkoBB/hari & 5 & 1.282 & 0.201 & & \\
\hline Zink 100 mgkgBB/hari & 5 & 1.465 & 0.335 & & \\
\hline
\end{tabular}

Berdasarkan hasil uji One Way ANOVA pada Tabel 2 menunjukkan bahwa rerata kadar MDA pada ke-enam kelompok perlakuan tersebut sama dengan nilai signifikan $\mathrm{p}=0.093(\mathrm{p}>0.05)$. Pada uji Tukey HSD menunjukkan bahwa rerata kadar MDA pada ke-enam kelompok perlakuan sama dengan nilai $\mathrm{p}=0.111(\mathrm{p}>0.05)$. Hasil ini dapat disimpulkan bahwa tidak ada kelompok perlakuan yang berpengaruh secara signifikan terhadap perbedaan rerata kadar MDA.

\section{Kualitas sperma}

Setelah dilakukan perlakuan pemberian zink selama 35 hari dan induksi penyuntikan obat cyclophosphamide dengan dosis $200 \mathrm{mg} / \mathrm{kgBB}$ secara intraperitoneal 1 kali setiap minggu selama 35 hari terhadap kualitas sperma pada masing-masing kelompok.

Pemeriksaan kualitas sperma mencit jantan (Mus musculus) pada penelitian ini berdasarkan pada jumlah sperma (sel sperma). Hasil pengamatan rerata kualitas sperma mencit jantan (Mus musculus) pada semua kelompok perlakuan dapat dilihat pada Tabel 3 dan Gambar 2.

Tabel 3. Rerata jumlah sel sperma mencit (Mus musculus) setelah perlakuan dengan pemberian Zink selama 35 hari. 
Jurnal Biosains Pascasarjana Vol.22(2020) pp

(C) (2020) Sekolah Pascasarjana Universitas Airlangga, Indonesia

\begin{tabular}{lcc}
\hline Kelompok Perlakuan & Pengulangan & $\begin{array}{c}\text { Jumlah Sel Spermatozoa } \\
\text { (mikroliter) }\end{array}$ \\
\hline Kontrol Negatif & 5 & $1490 \pm 0.175$ \\
\hline Zink & 5 & $790 \pm 0.160$ \\
\hline Cyclophosphamide & 5 & $580 \pm 0.176$ \\
\hline $\begin{array}{l}\text { Zink 25 } \\
\mathrm{mg} / \mathrm{kgBB} / \text { hari }\end{array}$ & 5 & $380 \pm 0.778$ \\
\hline $\begin{array}{l}\text { Zink 50 } \\
\mathrm{mg} / \mathrm{kgBB} / \text { hari }\end{array}$ & 5 & $370 \pm 0.258$ \\
\hline $\begin{array}{l}\text { Zink 100 } \\
\mathrm{mg} / \mathrm{kgBB} / \text { hari }\end{array}$ & 5 & $240 \pm 0.054$
\end{tabular}

\begin{tabular}{|c|c|c|c|c|c|c|}
\hline Kelompok Perlakuan & N & Rata-rata & SD & \multicolumn{2}{|c|}{$\begin{array}{l}\text { Post Hoc test } \\
\text { Tukey HSD }\end{array}$} & $p$ \\
\hline Kontrol Negatif & 5 & 1.386 & 0.359 & 0.041 & 0.008 & 0.011 \\
\hline Zink & 5 & 1.105 & 0.371 & & & \\
\hline Cyclophosphamide & 5 & 0.969 & 0.311 & & & \\
\hline Zink $25 \mathrm{mgkgBB}$ hari & 5 & 0.798 & 0.324 & 0.041 & & \\
\hline Zink $50 \mathrm{mg} \mathrm{kgBB}$ hari & 5 & 0.842 & 0.169 & & & \\
\hline Zink $100 \mathrm{mg} / \mathrm{kBB} /$ hari & 5 & 0.67 & 0.113 & & 0.008 & \\
\hline
\end{tabular}

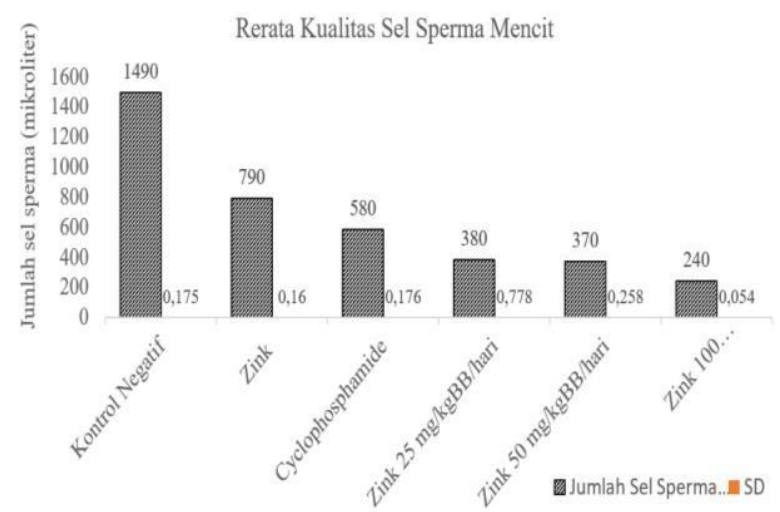

Berdasarkan hasil uji One Way ANOVA pada Tabel 4 menunjukkan bahwa rerata jumlah sel sperma pada ke-enam kelompok perlakuan tersebut berbeda dengan nilai signifikan $\mathrm{p}=0.011$ $(\mathrm{p}<0.05)$. Pada uji Tukey HSD menunjukkan bahwa kualitas sperma berdasarkan jumlah sel sperma pada kelompok kontrol negatif terhadap kelompok Zink dosis

$25 \mathrm{mg} / \mathrm{kgBB} / \mathrm{hari}$ yang diinduksi $\mathrm{CP}$ dan kelompok Zink dosis $100 \mathrm{mg} / \mathrm{kgBB} /$ hari yang diinduksi CP berbeda dengan nilai $\mathrm{p}$ masingmasing adalah 0.041 dan 0.008 , sedangkan rerata kelompok lainnya adalah sama. Hasil ini dapat disimpulkan bahwa kelompok perlakuan yang berpengaruh secara signifikan terhadap perbedaan rerata jumlah sel sperma kelompok K1, K4, dan K6.

Selanjutnya data tersebut dianalisis dengan uji statistik untuk membandingkan data jumlah sel sperma pada semua kelompok perlakuan. Karena syarat uji One Way ANOVA terpenuhi yakni data terdistribusi secara normal dengan uji Shapiro-Wilk test nilai signifikansi p >0.05 dan homogenitas data didapatkan homogen dengan uji Levene nilai signifikansi $\mathrm{p}=0.435$ (p>0.05). Hasil uji disajikan pada Tabel 2.

Tabel 4. Hasil uji One Way ANOVA rerata jumlah sel sperma mencit (Mus musculus) pada kelompok perlakuan setelah perlakuan dengan pemberian Zink selama 35 hari.

\section{Hubungan kadar MDA testis dengan kualitas sperma mencit jantan (Mus musculus)}

Hasil analisis korelasi diperoleh koefisien korelasi (r) antara kadar MDA testis dengan kualitas sperma (jumlah sperma) dapat dilihat pada

Tabel 5. Analisis korelasi Pearson antara kadar MDA testis dengan kualitas sperma mencit jantan (Mus musculus)

Tabel 5. Korelasi Pearson antara kualitas sperma dengan kadar MDA testis mencit (Mus musculus) setelah perlakuan dengan pemberian Zink selama 35 hari. 
Jurnal Biosains Pascasarjana Vol.22(2020) pp

(C) (2020) Sekolah Pascasarjana Universitas Airlangga, Indonesia

\begin{tabular}{llrr}
\hline & & \multicolumn{1}{c}{$\begin{array}{c}\text { Jumlah sel } \\
\text { spermatozoa }\end{array}$} & \multicolumn{2}{c}{$\begin{array}{l}\text { Kadar MDA } \\
\text { testis }\end{array}$} \\
\hline Jumlah sel & $\begin{array}{l}\text { Pearson } \\
\text { Correlation }\end{array}$ & 1 & -0.048 \\
spermatozoa & $\begin{array}{l}\text { Sig. (2- } \\
\text { tailed) }\end{array}$ & & 0.800 \\
& $\mathrm{~N}$ & 30 & 30 \\
\hline \multirow{3}{*}{$\begin{array}{l}\text { Pearson } \\
\text { Kadar MDA }\end{array}$} & $\begin{array}{l}\text { Correlation } \\
\text { Sig. (2- } \\
\text { tailed) }\end{array}$ & -0.048 & 1 \\
& $\mathrm{~N}$ & 0.800 & \\
& & 30 & 30 \\
\hline
\end{tabular}

Berdasarkan Tabel 5 hasil analisis korelasi Pearson di atas menunjukkan bahwa tidak terdapat hubungan yang nyata $(\mathrm{p}=0,800)$ antara kadar MDA testis dengan jumlah sel sperma. Nilai koefisien korelasi $\mathrm{r}=-0,048$ adalah tidak ada korelasi yang artinya tidak ada keeratan hubungan kadar MDA testis dengan jumlah sel sperma. Nilai negatif pada (r) menunjukkan arah korelasi negatif yang menunjukkan semakin rendah kadar MDA testis, maka jumlah sperma semakin meningkat.

Masalah kesuburan pada pria dapat diakibatkan oleh stres oksidatif dalam jaringan testis. Ketidaksuburan dikaitan dengan proses spermatogenesis. Banyak faktor-faktor yang mempengaruhi proses pemkembangan sel sperma baik dari luar maupun dalam tubuh. Pasien pria yang mendapatkan pengobatan antikanker seperti cyclophosphamide (CP) memiliki risiko untuk terjadi gangguan kesuburaan. Karena zat buangan hasil metabolit CP berupa Acrolein memiliki sifat sebagai aldehyde reactive yang dapat merusak sel melalui mekanisme deplesi jalur seluler GSH yang terkonjugasi, sehingga proses cytotoxicity dapat terjadi secara luas. Selain itu juga Acrolein juga memiliki efek terhadap DNA yang menyebabkan terbentuknya Interstrand DNA dan DNA-protein cross-links sehingga akan mengganggu proses replikasi DNA normal tubuh (BC Cancer Agency Cancer Drug Manual@, 2013). Akibat gangguan mekanisme jalur GSH peroksidase menyebabkan gangguan keseimbangan reaksi oksidatif jaringan sehingga jaringan mengalami stress oksidatif. Hasil stress oksidatif terbentuknya hidrogen peroksida yang mampu menyebabkan dekomposisi produk aldehid yang bersifat toksik terhadap sel yang akan berdampak pada gangguan perkembangan spermatogenesis O.Abarikwu, 2012).

Malondialdehida (MDA) merupakan indikator terjadinya stres oksidatif suatu jaringan. Malondialdehid merupakan salah satu senyawa produk radikal bebas pada proses reaksi peroksidasi lipid di membran sel melalui reaksi oksidasi reduksi yang terjadi secara berantai dan terus menerus sehingga terbentuk molekul yang mempunyai sekelompok atom dengan elektron yang tidak berpasangan yang bersifat reaktif sehingga menyebabkan kerusakan membran dan organel sel. Radikal bebas yang paling banyak terbentuk di dalam tubuh adalah superoksida yang diubah menjadi hidrogen peroksida $\left(\mathrm{H}_{2} \mathrm{O}_{2}\right)$ yang akan bereaksi dengan Poly Unsaturated Fatty Acid (PUFA) pada membran sel yang dikenal dengan reaksi peroksidasi lipid dan menghasilkan hidrogen peroksidasi yang dapat menyebabkan dekomposisi produk aldehid yang bersifat toksik terhadap sel, salah satunya adalah malondialdehida (MDA). Jika ini terjadi terus menerus akan menyebabkan ketidak seimbangan antara radikal bebas dengan antioksidan endogen yang disebut dengan stres oksidatif (Deslo, Jauhari; Ismy, Jufriady; Dasrul, 2019), (Parwata, 2015).

Diketahui bahwa zink merupakan trace mineral yang esesensial bagi kehidupan manusia, meski dibutuhkan sedikit tetapi tetap dijaga agar tidak toksik karena perannya yang sangat vital. Zink memiliki fungsi secara seluler baik sebagai katalitik, dimana aktivitas zink sangat berperan dalam proses enzimatik, lalu sebagai struktural, zink menjaga kestabilan struktur protein dan membran sel dan sebagai regulasi, zink memiliki peran dalam meregulasi ekspresi gene sebagai faktor transkripsi serta berperan dalam cell signalling dan pelepasan hormon dan transmisi impuls serta berperan dalam meningkatkan daya tahan tubuh. Dalam reproduksi, suplemen Zink dapat meningkatkan jumlah dan motilitas sperma.

Berdasarkan hasil penelitian ini terlihat Tabel 1 pada kelompok kontrol negatif yang tidak mendapatkan $\mathrm{CP}$ dan $\mathrm{Zn}$ (K1) terdapat kadar MDA testis 11.9 \pm 0.259 mikroMolar lebih 
rendah dibandingkan kelompok kontrol positif dan kelompok perlakuan $\mathrm{Zn}$ dan CP. Hal ini menunjukkan bahwa meskipun tikus dalam keadaan normal atau sehat dapat terbentuk senyawa MDA tetapi dalam kadar yang lebih rendah dibandingkan dengan kadar MDA pada keadaan tikus yang mendapatkan pengobatan cyclophosphamide. Hal ini sesuai dengan penelitian yang menyatakan bahwa pada keadan normal dapat terjadi peningkatan produksi ROS berupa senyawa MDA yang merupakan hasil reaksi oksidasi reduksi /lipid peroksidas di membran sel yang dihasilkan selama metabolisme di mitokondria pada sel yang normal. Pada organ testis terutama di tubulus seminiferus terjadi respon fisiologis (ROS endogen) yaitu hasil metabolisme sel normal sebagian kecil merupakan hasil paparan dari luar tubuh (ROS eksogen). Namun, proses fisiologi normal tersebut terganggu akan menyebabkan produksi ROS yang berlebihan hingga menyebabkan kerusakan sel (Deslo, Jauhari; Ismy, Jufriady; Dasrul, 2019), (Pasupathi, 2009).

Meski terjadi peningkatan produksi ROS pada kelompok K1 namun tidak mempengaruhi jumlah sel sperma yang dihasilkan. Hal ini terlihat pada Tabel 3 kelompok K2 menunjukkan bahwa jumlah sel spermatozoa lebih tinggi dibandingkan dengan kelompok perlakuan lainnya. Kemungkinan ini disebabkan keseimbangan enzim-enzim antioksidan tidak terganggu sehingga radikal bebas yang terbentuk masih bisa dinetralisir.

Reaksi fisiologi normal yang terganggu menyebabkan terjadinya peningkatan ROS dalam sirkulasi karena pemberian obat cyclophosphamide. Dalam penelitian ini dapat terlihat bahwa pada kelompok kontrol yang hanya diberi $\mathrm{CP}(\mathrm{K} 3)$ terdapat kadar MDA testis 19.7 \pm 0.266 mikroMolar lebih tinggi dibandingkan dengan kontrol negatif yang tidak mendapatkan CP dan Zn. Hal ini membuktikan selama pemberian CP terjadi aktivasi enzim sel hepatosit yaitu Cytochrome P450 enzyme system (CYP) yang menghasilkan zat aktif sebagai ankylating agent, dan zat buangan hasil metabolit yaitu Phosparamide Mustard (PM) dan Acrolein. Acrolein sebagai aldehyde reactive menjadi penyebab utama kerusakan sel melalui mekanisme deplesi jalur seluler GSH, sehingga proses cytotoxicity dapat terjadi secara luas (BC Cancer Agency Cancer Drug Manual(, 2013). Paparan CP menyebabkan gangguan keseimbangan aktivitas pertahanan antioksidan enzimatik seperti superoksida dismutase, katalase, gluthation peroksidase dan asam askorbat dengan radikal bebas yang dihasilkan $\mathrm{CP}$ menyebabkan stress oksidatif jaringan testis yang mengganggu fungsi normal perkembangan spermatogenesis (S. O.Abarikwu, 2012). Akibatnya terjadi kerusakan seluler dan apoptosis sel spermatozoa yang mempengaruhi jumlah spermatozoa. Dalam penelitian ini dapat dilihat pada Tabel 3 yang memperlihatkan kelompok perlakuan yang mendapatkan $\mathrm{CP}(\mathrm{K} 3, \mathrm{~K} 4, \mathrm{~K} 5$ dan K6) terlihat jumlah sel sperma (spermatozoa) terjadi penurunan dibandingkan dengan jumlah sel sperma pada kelompok kontrol negatif (K1) dan kelompok yang hanya diberikan $\mathrm{Zn}(\mathrm{K} 2)$.

Kemudian pada kelompok kontrol yang hanya diberi $\mathrm{Zn} 100 \mathrm{mg} / \mathrm{kgBB}$ (K2) terdapat kadar MDA testis adalah 13.3 \pm 0.175 mikroMolar lebih tinggi dibandingkan dengan kelompok kontrol negatif yang tidak mendapatkan $\mathrm{CP}$ dan $\mathrm{Zn}$ tetapi lebih rendah dari kelompok kontrol positif yang hanya diberi CP (K3). Hal ini dikarenakan konsumsi Zn dalam jumlah tinggi ( $\geq 50 \mathrm{mg}$ per hari) dalam waktu mingguan dapat mempengaruhi bioavaibilitas $\mathrm{Cu}$ dan menginduksi sintesis copper-bindingprotein (metallothionein) yang menyebabkan penyerapan $\mathrm{Cu}$ terhambat. Hal ini akan berakibat berkurangnya perlindungan terhadap stres oksidatif. Dengan demikian terjadi peningkatan radikal bebas yang ditandai dengan peningkatan kadar MDA yang melebihi kontrol negatif dan berdampak pada penurunan jumlah sel sperma sebesar 790 \pm 0.160 mikroliter (Tabel $3)$.

Pada kelompok perlakuan yang mendapatkan induksi $\mathrm{CP}$ selama 5 minggu dengan dosis $200 \mathrm{mg} / \mathrm{kgBB}$ atau 0,4 cc tiap minggu dan pemberian $\mathrm{Zn}$ setiap hari dengan dosis bertingkat $25 \mathrm{mg}$ (K4), $50 \mathrm{mg}$ (K5) dan $100 \mathrm{mg}$ (K6) terlihat pada hasil pemeriksaan rerata kadar MDA dan kualitas sperma (Tabel 1 dan 3) terjadi kecenderungan peningkatan kadar 
MDA yang lebih tinggi dan penurunan jumlah sel sperma dibandingkan dengan kontrol negatif. Hal ini disebabkan karena pembentukan radikal bebas dalam sirkulasi akibat pemberian $\mathrm{CP}$ dan mengganggu penyempurnaandan terjadinya defisiensi $\mathrm{Cu}$ akibat pemberian $\mathrm{Zn}$ dosis tinggi sehingga perlindungan terhadap radikal bebas berkurang, namun pada kelompok perlakuan $\mathrm{Zn}$ dosis $25 \mathrm{mg}$ meski nilai kadar MDA lebih tinggi dari kelompok kontrol K2 $(12.5 \pm 0.350$ mikroMolar) tetapi tidak disertai dengan peningkatan jumlah sel sperma. Hal ini mungkin disebabkan karena stres oksidatif akibat CP menyebabkan poros hipotalamushipofisia-gonad terganggu sehingga mempengaruhi sekresi dan kerja hormon Follikel Stimulating Hormone (FSH) dan Luteinizing Hormone (LH). Kerja FSH berperan dalam proses pematangan sel spermatogonia dan spermatosit primer, mempengaruhi mitosis dan meiosis hingga terbentuknya spermatozoa, sedangkan LH berperan dalam proses spermatogenesis. Selain itu $\mathrm{Zn}$ memiliki peran dalam menstimulasi hormon testosteron pada sel Leydig. Bila terjadi penurunan jumlah sel Leydig maka akan berpengaruh pada penurunan kadar hormon testosteron yang akan menghambat proses spermatogenesis dan penurunan jumlah spermatozoa (Deslo, Jauhari, 2019) (Oktapiani, Kory, 2014).

Hasil analisis korelasi Pearson menunjukkan tidak berkorelasi antara kadar MDA dengan jumlah sel spermatozoa dengan nilai signifikansi $\mathrm{p}=0.800$, nilai derajat korelasi (r) adalah -0.048. Hasil ini menunjukan bahwa tidak ada hubungan yang antara antara kadar MDA dengan jumlah sel spermatozoa pada masing-masing kelompok perlakuan. Nilai negatif pada nilai korelasi (r) menunjukkan arah korelasi negatif yang berarti bahwa semakin rendah kadar MDA testis akan menyebabkan semakin meningkat jumlah spermatozoa.

\section{KESIMPULAN}

Berdasarkan hasil analisis dan pembahasan yang telah diuraikan oleh peneliti, dapat diambil kesimpulan bahwa terdapat tidak hubungan yang kuat antara kadar MDA testis dengan kualitas sperma (jumlah spermatozoa) mencit (Mus musculus) dengan nilai $\mathrm{p}=0.800$ dan nilai $\mathrm{r}=-0,795$. Semakin tinggi kadar MDA testis semakin rendah jumlah spermatozoa tikus putih diabetes.

\section{Ucapan Terima Kasih}

Penulis mengucapkan terima kasih kepada LPPM Universitas Pembangunan Nasional Veteran Jakarta atas ijin dan bantuan dana dalam penelitian ini.

\section{DAFTAR PUSTAKA}

Abarikwu, S.O; Otuechere, C. A; Ekkor, M; Monwuba, K; and Osobu, D. (2012). Rutin Ameliorates Cyclophosphamide-induced Reproductive Toxicity in Male Rats. Toxicol Int, 19(2), 207-214. https://doi.org/doi: $\quad 10.4103 / 0971-$ 6580.97224

Deslo, Jauhari; Ismy, Jufriady; Dasrul, D. (2019). Hubungan Kadar Malondialdehide (MDA) Testis dengan Kualitas Spermatozoa pada Tikus Putih Strain Wistar (Rattus novergicus) Diabetes Tipe I. Indonesian J Surg, 47(2), 82-110. www.jibiikabi.org

Drumond,Ana Luiza; Weng, Connie C; Wang, Gensheng; Garcia, Helio Chiarini; Garcia, Leticia Eras and Meistrich, M. L. (2011). Effects of multiple doses of cyclophosphamide on mouse testes: Accessing the germ cells lost, and the functional damage of stem cells. Reprod Toxicol, 32(4), 395-406. https://doi.org/doi:

10.1016/j.reprotox.2011.09.010

Elangovan, N; Chiou,Tzeon-Jye; Tzeng,Woan-

Fang; Chu, S.-T. (2006). Cyclophosphamide treatment causes impairment of sperm and its fertilizing ability in mice. Toxicology, 222, 60-70. https://doi.org/doi:10.1016/j.tox.2006.01. 027

Oktapiani, Kory; Wantouw; Tendean, L. (2014). Pengaruh Pemberian Zink Terhadap Kualitas Spermatozoa Pada Mencit Jantan (Mus musculus)No Title. 
Jurnal E-Biomedik, 2(2), 496-500.

https://media.neliti.com/media/publicati ons/64471-ID-none.pdf

Parwata, I. M. O. A. (2015). Antioksidan.

Program Pascasarjana, universitas Udayana.

Pasupathi, P. (2009). Glutathione, GlutathioneDependent Enzymesand Antioxidant Status in Gastric Carcinoma Patients. Journal of Applies Biomedicine, 7(2), 101-109.

Yulianti,Retno and Astari, R. V. (2020). Efektivitas Ekstrak Daun Sirsak (Annona muricata) Dan Latihan Fisik Serta Kombinasi Terhadap Kadar Malondialdehid Hepar Pada Model Tikus Hiperkolesterolemia-Diabetes. Jurnal Kesehatan Published By Poltekkes Ternate, 13(1), 11-18. 